\title{
Plasma-fuel systems for clean coal technologies
}

\author{
Vladimir Messerle Dr. rer. techn. \\ Professor, Kutateladze Institute of Thermophysics of SB RAS, Novosibirsk, \\ Russia, Combustion Problems Institute, Almaty, Kazakhstan \\ (Orcid:0000-0003-4281-1429)

\section{Alexandr Ustimenko Dr. rer. techn.} \\ Leading Researcher, Plasmatechnics R\&D, Institute of Experimental and \\ Theoretical Physics of al-Farabi Kazakh National University, Almaty, \\ Kazakhstan (corresponding author: ust@physics.kz) \\ (Orcid:0000-0002-2629-6167)
}

Oleg Lavrichshev PhD

Assistant Professor, Plasmatechnics R\&D, Institute of Experimental and Theoretical Physics of al-Farabi Kazakh National University, Almaty, Kazakhstan (Orcid:0000-0002-5934-8381)

This paper presents plasma technology for pulverised-coal ignition and improving energy efficiency of power stations. Plasma-fuel systems (PFS) were developed to accomplish this technology. PFS are a combination of pulverised-coal burners with arc plasmatrons. The main idea of the technology using PFS is to replace the traditionally used fuel oil for flame stabilisation and starting coal-fired boilers with the products of plasma chemically treated pulverised-coal. The coal-air mixture is fed into the PFS where the plasmatron induces heating, devolatilisation and gasification of the coal particles and partial oxidation of the char carbon. As a result, a highly reactive two-component fuel (mixture of combustible gases and partially oxidised char particles) is formed at the exit of the PFS. At the entry to the furnace, this highly reactive two-component fuel is easily ignited. PFS increase the efficiency of coal ignition and combustion, eliminate fuel oil expenditure for boiler start-up and flame stabilisation and decrease unburned carbon, nitrogen oxides $\left(\mathrm{NO}_{x}\right)$, sulfur oxides $\left(\mathrm{SO}_{x}\right)$ and vanadium (V) oxide emissions. PFS have been tested at 30 coal-fired power stations and steam coals of all ranks were used. The volatile content of steam coals varied from 4 to $50 \%$; ash from 15 to $56 \%$; and heat of combustion from 6700 to $25000 \mathrm{~kJ} / \mathrm{kg}$.

\section{Notation \\ $A^{\mathrm{d}} \quad$ ash content on dry basis \\ $Q_{1}^{\mathrm{w}} \quad$ low calorific value on dry basis \\ $V^{\text {daf }} \quad$ volatilisation on dry basis \\ $W^{\mathrm{w}} \quad$ moisture on dry basis}

\section{Introduction}

More than half of the world's combined electrical and thermal energy is currently produced by the combustion of pulverised coal. The analyses of coal resources (Messerle et al., 2014) show that coal-derived energy has the potential to remain as a principal source of energy throughout the twenty-first century. Coal-fired utility boilers face two problems: first, the necessity to use expensive oil for start-up and second, the increased commercial pressure requiring operators to burn a broader range of coals, possibly outside the specifications envisaged by the manufacturer's assurances for the combustion equipment. Each of these problems results in a negative environmental impact. Oil firing for start-up increases the gaseous and particulate burden of the plant. The firing of poorer-quality coals has two disadvantages: reduced flame stability performance necessitating oil support and its consequential emissions and cost implications; and reduced combustion efficiency due to an increased amount of carbon in the residual ash, resulting in an increase of emissions per megawatt of power generated.
Plasma-assisted coal combustion represents an effective and ecologically friendly technology, which is equally applicable to alternative 'green' solid fuels. The basis of plasma-assisted coal combustion is thermochemical plasma preparation of coal for burning. This technology addresses the above problems in power stations. In the framework of this technology some portion of pulverised-solid fuel ( $\mathrm{pf}$ ) is separated from the main pf flow and undergoes activation by arc plasma in a special chamber - a plasma-fuel system (Figure 1).

The air plasma jet is a source of heat and additional oxidation, it provides a high-temperature medium enriched with radicals, where the fuel mixture is heated, volatile components of coal are extracted and carbon is partially gasified. This active blended fuel can ignite the main pf flow supplied into the furnace. This technology provides boiler start-up and stabilisation of pf flame and eliminates the necessity for additional highly reacting fuel.

PFS have been tested for boiler plasma start-up and flame stabilisation in different countries at 30 coal-fired power stations where steam productivity was found to be $75-670 \mathrm{t} / \mathrm{h}$, and which were equipped with different types of pulverised-coal burners (Messerle et al., 2014). The Yantai Longyuan Electric Power Technology Company (China) has distributed PFS to 700 boilers in China with an installed capacity of 300 million kW (Karpenko et al., 2009). The developed and industrially tested PFS improved 


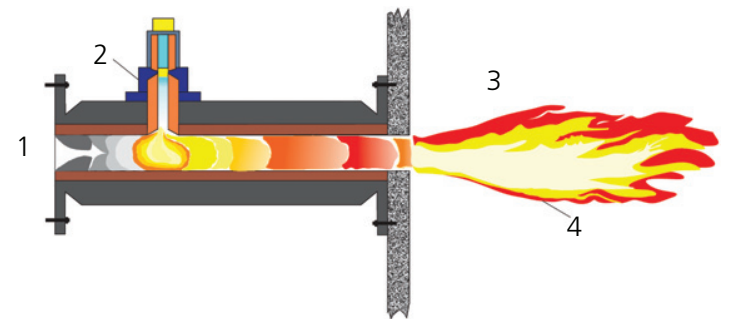

Figure 1. Sketch of a plasma-fuel system: 1 - coal-air mixture; 2 - plasmatron; 3 - furnace; 4 - pf flame

coal combustion efficiency and decreased harmful carbon dioxide emissions from pulverised-coal-fired power stations.

The following are the advantages of plasma technology of oil-free boiler start-up and flame stabilisation over conventional technology (Messerle et al., 2013; Messerle and Ustimenko, 2014).

- Reduction in fuel oil or gas consumption at thermal power plants; power efficiency of plasma-fuel systems (PFS) is 3-4 times higher, because the relative electric capacity of plasmatrons makes up (depending on type of coal and burner) only $0 \cdot 5-2 \%$ of heat capacity of a pulverised-coal burner.

- Replacement of stabilising fuel (fuel oil or natural gas) by coal enables the reduction of the formation of nitrogen oxides by $40-50 \%$ due to the conversion of fuel nitrogen into molecular nitrogen in oxygen-depleted zones of ignition and combustion, the reduction of emissions of sulfur oxides by $30-40 \%$ (in case when high-sulfur fuel oil is replaced), and emissions of vanadium pentoxide are almost completely removed, since vanadium is found only in fuel oil.

- The overall quantity of carbon dioxide emissions is reduced due to improved efficiency of the combustion process in pulverised-coal boilers as a result of a decrease in unburned carbon of the fuel.

- Provides opportunities for process automation and the ability to fire-up power units of pulverised-coal thermal power plants in which there is no steam for the plant's own needs.

- Use of wide range of power-generating coals, lignite, oil shale, peat, biomass and their mixtures while technical, economic and ecological indexes of power units are the same.

- Use of PFS during flame stabilisation at thermal power plants decreases unburned carbon by $40-50 \%$ and nitrogen oxides by $50-60 \%$ and carbon dioxide emissions can be reduced by $1-2 \%$.

\section{Basic principles of plasma-energy technology}

The main objective of the paper is to present a plasma technology for the thermochemical preparation of steam coals for combustion and the success of PFS in pulverisedcoal-fired power plants. PFS improved the environmental and economic performance of power plants. When using PFS, highly reactive fuel is replaced with coal dust subjected to thermochemical preparation in the PFS using an electric arc plasmatron - the main element of PFS.

The results obtained allowed formulation of the main principles of design of PFS for use in industry. Gorokhovski et al. (2007) have shown that across the plasma jet, coal particles with an initial size of $50-100 \mu \mathrm{m}$ experience 'heat shock' and disintegrate into fragments of 5-10 $\mu \mathrm{m}$. This increases the active interface of the particles, significantly accelerating the devolatilisation (carbon monoxide, carbon dioxide, hydrogen, nitrogen, methane, benzene and others) and accelerates the process of oxidation of fuel combustibles by 3-4 times.

Consider a burner with a flow of coal and primary/transport air. Oxygen for combustion is in deficit, the excess air factor being less than 0.5 . Introducing a plasma source heats the coal/air mixture to the temperature that brings about complete devolatilisation and induces partial gasification of the char carbon, producing a highly reactive two-phase fuel (combustible gas and char carbon). This highly reactive fuel initiates the oxidation of the remaining coal. Since the primary/ transport air is deficient in oxygen, the carbon is oxidised mainly to carbon monoxide, which further enhances the reactivity of the hot mixture in the burner. This mixture, injected

Table 1. Thermotechnical characteristics of coals

\begin{tabular}{lcccc} 
Coal type & $\boldsymbol{W}^{\mathbf{w}}: \mathbf{\%}$ & $\boldsymbol{A}^{\mathbf{d}:} \mathbf{\%}$ & $\boldsymbol{V}^{\text {daf: }} \mathbf{\%}$ & $\mathbf{Q}_{\mathbf{1}}^{\mathbf{w}}: \mathbf{k J} / \mathbf{k g}$ \\
\hline Brown & $25-35$ & $15-20$ & $35-50$ & $12500-16000$ \\
Shale & $40-50$ & $75-80$ & $48-50$ & $6700-8500$ \\
Bituminous & $5-12$ & $20-45$ & $15-40$ & $16500-21000$ \\
Anthracite & $5-8$ & $25-35$ & $4-10$ & $18000-26000$ \\
Mixture of coals & $10 \cdot 4$ & $48 \cdot 5$ & $38 \cdot 2$ & 13150
\end{tabular}

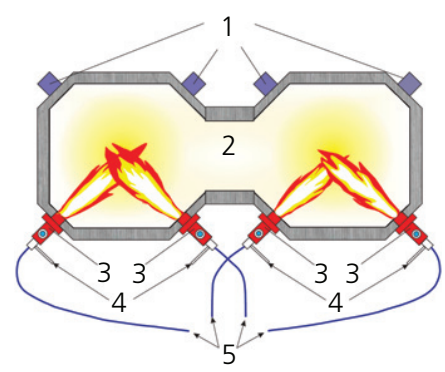

Figure 2. Scheme of the industrial furnace of BKZ-640-140 boiler (Gusinoozersk power station, Russia) equipped with four PFS (top view): 1 - pf burners; 2 - furnace; 3 - PFS; 4 - air; 5 - coal-air mixture 
Table 2. Chemical analysis of Tugnuiski bituminous coal (on dry basis), wt\%

\begin{tabular}{lccccccccccc}
$\mathbf{C}$ & $\mathbf{O}$ & $\mathbf{H}$ & $\mathbf{N}$ & $\mathbf{S}$ & $\mathrm{SiO}_{2}$ & $\mathrm{Al}_{2} \mathrm{O}_{3}$ & $\mathrm{Fe}_{2} \mathrm{O}_{3}$ & $\mathrm{CaO}$ & $\mathrm{MgO}$ & $\mathrm{Na}_{2} \mathrm{O}$ & $\mathrm{K}_{\mathbf{2}} \mathrm{O}$ \\
\hline 61.7 & 13.2 & 4.1 & 1.2 & 0.39 & 10.99 & 4.34 & 1.94 & 1.16 & 0.35 & 0.16 & 0.12
\end{tabular}

$\mathrm{C}$, carbon; $\mathrm{O}$, oxygen; $\mathrm{H}$, hydrogen; $\mathrm{S}$, sulfur; $\mathrm{SiO}_{2}$, silicon dioxide; $\mathrm{Al}_{2} \mathrm{O}_{3}$, aluminium oxide; $\mathrm{FeO}_{2}$, iron oxide; $\mathrm{CaO}$, calcium oxide; $\mathrm{MgO}$, magnesium oxide; $\mathrm{Na} 2 \mathrm{O}$, sodium oxide; $\mathrm{K}_{2} \mathrm{O}$, potassium oxide

into the furnace, promotes the ignition of the main part of the non-treated coal, which with the secondary air is fed into the furnace through conventional burners.

\section{Industrial tests}

The PFS have been tested on a bench scale and under industrial conditions for different types of power-generating coals (shale, brown coal, bituminous coal and anthracite, including mixtures of lignite and high-ash anthracite coal) (Matveeva et al., 1979). The characteristics of the coals used are given in Table 1 . The volatile yields vary from 4 to $50 \%$, the ash contents from 15 to $80 \%$ and the calorific values from 6700 to $26000 \mathrm{~kJ} / \mathrm{kg}$.

The PFS have been incorporated into a range of furnaces of coal-fired power stations (Karpenko et al., 2007; Messerle et al., 2013; Messerle and Ustimenko, 2014). The technology has been tested successfully on pulverised-coal boilers for steam productivity ranging from 75 to $950 \mathrm{t} / \mathrm{h}$ in 30 power stations located in eight countries (Russia, Kazakhstan, Korea, Ukraine, Slovakia, Mongolia, Serbia and China). These combustors were fitted with different systems of pulverised-coal-firing systems such as direct pf injection and indirect systems where the pf is fed from storage hoppers. In total, more than 90 PFS have been mounted and tested on boiler combustors.

For example, PFS have been incorporated in the furnace of a $640 \mathrm{t} \mathrm{steam} / \mathrm{h}$ full-scale steam-raising boiler (Gusinoozersk power station, Eastern Siberia, Russia). A schematic view of the furnace equipped with PFS is shown in Figure 2. The furnace consists of two symmetrical combustion chambers (semifurnaces), each provisioned with eight tangentially directed pf burners in two layers. The combustion chambers are interconnected by a central section. Each burner comprises a primary air/pf delivery section and a secondary air section. Four PFS take the place of the four lower layer burners as shown on the right side of Figure 2. The plasmatrons operate during the boiler warm-up period and in the case of an unstable flame. When the boiler performance is stabilised, the plasmatrons are switched off and the PFS continue to function as conventional pf burners. In the case of flame instability, the plasmatrons are restarted. The fuel was Tugnuiski bituminous coal (Table 2). In total, four of the furnaces of this power station were equipped with 16 PFS. It is estimated that, since 1995, more than $20000 \mathrm{t}$ of fuel oil has been saved in this facility. This

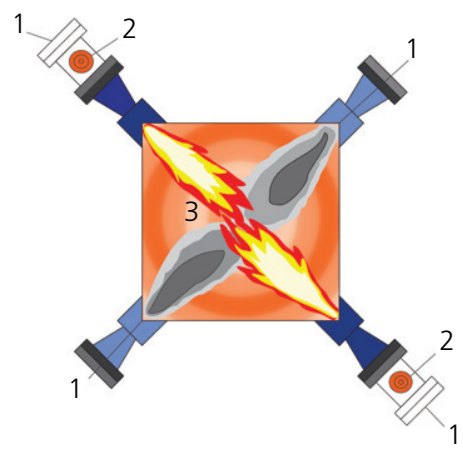

Figure 3. BKZ-420 boiler furnace equipped with two PFS (Ulan-Bator power station-4, Mongolia) (top view): 1 - coal-air mixture; 2 - PFS; 3 - furnace

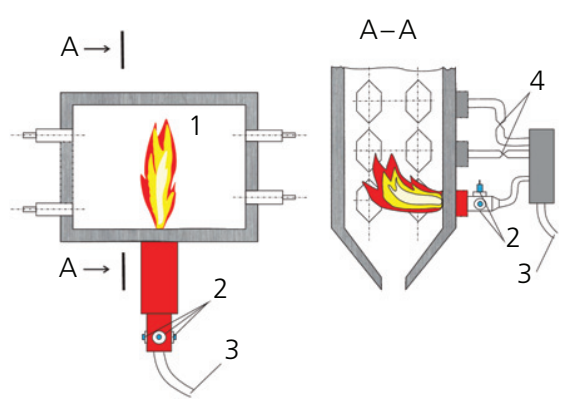

Figure 4. Scheme of arrangement of burners and PFS on BKZ-640 boiler (Gusinoozersk power station, Russia): 1 - furnace; 2 - plasmatron; 3 - coal-air mixture; 4 - gate

corresponds to a reduction in the emissions of nitrogen and sulfur oxides, carbon monoxide and vanadium pentoxide of some $13000 \mathrm{t}$ per year.

Figure 3 illustrates the scheme of arrangement of the PFS on the boiler combustor BKZ-420 in Ulan-Bator power station-4 (top view). Twelve corner-fired burners are placed at three elevations. Two PFS were mounted cornerwise on the lower layer. All eight boilers of the power plant were equipped with PFS for fuel oil-free boiler start-up. In 2-3 s after light-up with the PFS, the temperature of both pulverised-coal flames increased up to $1100-1150^{\circ} \mathrm{C}$. After $1 \mathrm{~h}$, the temperature of 
the flames had reached $1260-1290^{\circ} \mathrm{C}$ and the flames were about 7-8 $\mathrm{m}$ long. As per the operating instructions, the total duration of the boiler start-up was $4 \mathrm{~h}$.

Figure 4 demonstrates a scheme of arrangement of three plasma generators on a direct-jet flat-flame pulverised-coal

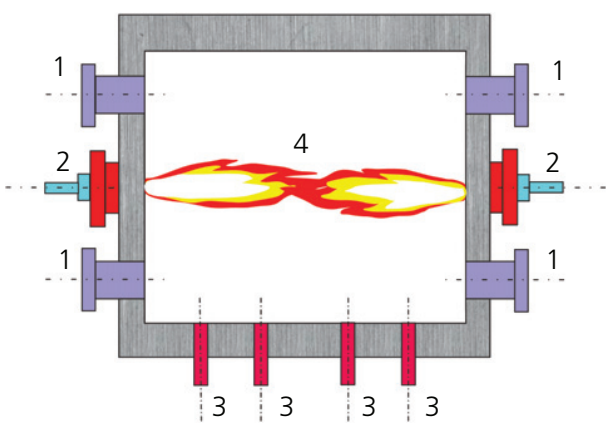

Figure 5. Scheme of the furnace of the boiler KVTK-100 (Neryungry power station, Russia) (top view): 1 - main burners; 2 - PFS; 3 - overflow burners; 4 - furnace
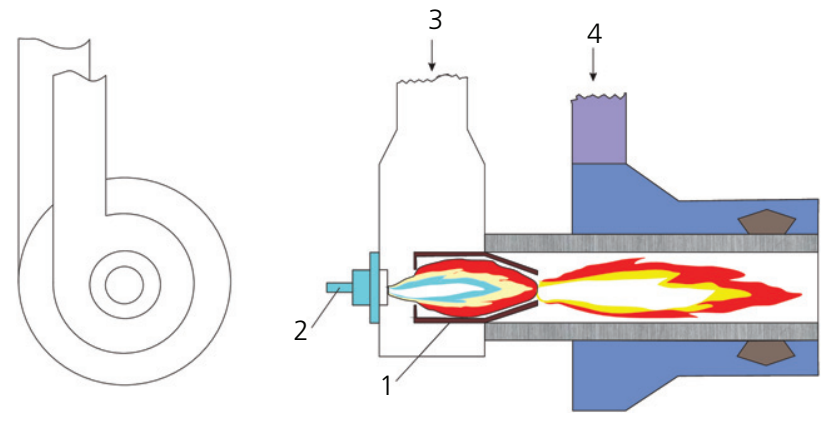

Figure 6. Scheme of the PFS installed on the furnace of the KVTK-100 boiler of the Neryungry power station: 1 - PFS: 2 - plasmatron; 3 - coal-air mixture; 4 - secondary air burner of the low layer of BKZ-640 boiler at Gusinoozersk power station (the left-hand image is the top view; the righthand image is a vertical section).

Figure 5 illustrates a scheme of arrangement of two plasmatrons on two vortex burners of the low layer of the boiler, which has a steam-generating capacity of $160 \mathrm{t} / \mathrm{h}$, at Neryungry power station (Russia). The scheme of arrangement of a plasma generator with a chamber for thermochemical treatment of fuels that is installed in the coal-air mixture snail is shown in Figure 6.

Table 3 presents the basic indexes of plasma-coal burners for low-grade coal ignition at thermal power plants in Russia, China and Slovakia. As can be seen from the table, the temperature of the flame varied from 1150 to $1400^{\circ} \mathrm{C}$ and the length from $2 \cdot 5$ to $6 \mathrm{~m}$.

Knowledge of the specific power consumption of a plasmatron is required to estimate PFS efficiency. This parameter is defined as the ratio of plasmatron electric power to pf consumption in the PFS. Figures 7(a) and 7(b) present experimental results for nitrogen oxides $\left(\mathrm{NO}_{x}\right)$ reduction and decrease of unburned carbon, respectively, during PFS operation plotted against plasmatronspecific power consumption. It can be seen that the $\mathrm{NO}_{X}$ concentration is halved, and the amount of unburned carbon is reduced by a factor of 4 . The decrease of nitrogen oxides is caused by the fact that the fuel nitrogen, released from the coal inside the PFS under conditions of oxygen deficiency, forms molecular nitrogen in the gas phase. Since the fuel nitrogen is evolved inside the PFS and converted into molecular nitrogen, mainly thermal nitrogen oxides are formed in the furnace volume. However, fuel nitrogen is the main source of nitrogen oxide emission from conventionally fired pf furnaces (Fine et al., 1974). Regarding unburned carbon (Figure 7(b)), its decrease indicates a fuel reactivity increase, which is explained by the enlargement of the reactive surface of coal particles due to 'heat explosion' and fragmentation due to their interaction with arc plasma.

Table 3. Basic indexes of PFS for low-rank coal ignition

\begin{tabular}{|c|c|c|c|c|}
\hline Feature & $\begin{array}{l}\text { Test bench of the Branch Centre } \\
\text { of Plasma-Energy Technologies, } \\
\text { Gusinoozersk, Russia }\end{array}$ & $\begin{array}{l}\text { Cherepetsk, } \\
\text { Russia }\end{array}$ & $\begin{array}{l}\text { Shaogyang, } \\
\text { China }\end{array}$ & $\begin{array}{l}\text { Voyany, } \\
\text { Slovakia }\end{array}$ \\
\hline Plasmatron power: kW & 320 & 150 & 320 & 260 \\
\hline Type of burner & Swirl burner & Direct-flow burner & Swirl burner & Swirl burner \\
\hline Primary air consumption: $\mathrm{m}^{3} / \mathrm{h}$ & 1800 & 2500 & 2100 & 3500 \\
\hline Maximum coal consumption: t/h & 3 & 3 & 4 & $4 \cdot 7$ \\
\hline Heat of coal combustion: MJ/kg & 25 & 23 & $19 \cdot 3$ & $25 \cdot 5$ \\
\hline Yield of volatiles: \% & 4 & 15 & $8 \cdot 2$ & $7 \cdot 5$ \\
\hline Ash: \% & 19 & 27 & $30 \cdot 5$ & $18 \cdot 7$ \\
\hline Fineness of milling, $R_{90}: \%$ & 48 & $15-20$ & 10 & 8 \\
\hline Temperature of the flame: ${ }^{\circ} \mathrm{C}$ & 1200 & 1150 & 1170 & 1400 \\
\hline Length of the flame: $m$ & $2 \cdot 5$ & 6 & 4 & 4 \\
\hline
\end{tabular}




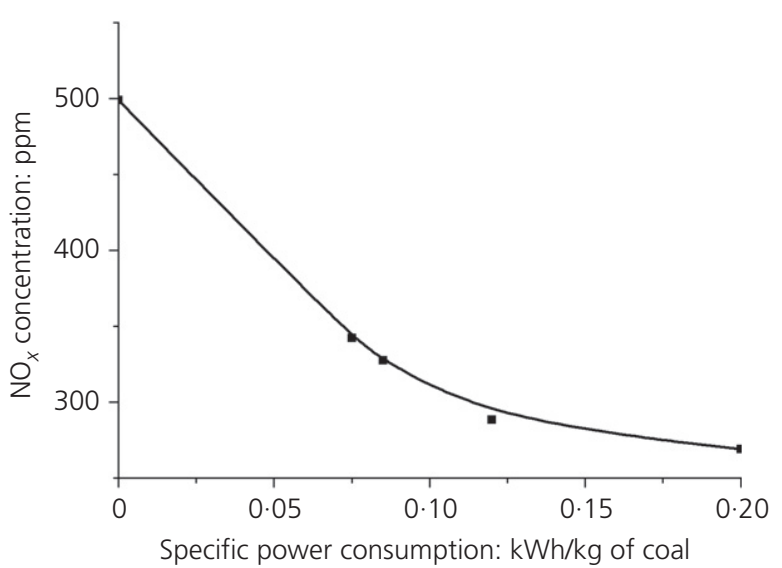

(a)

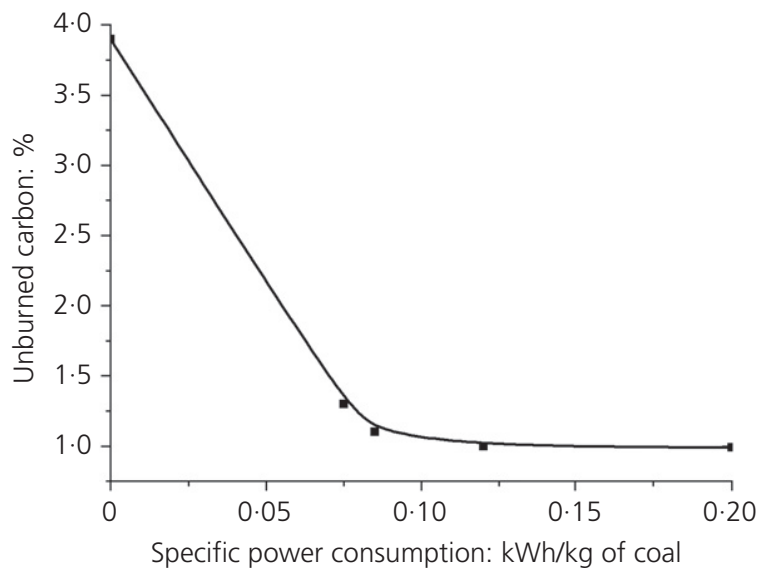

(b)

Figure 7. Specific power consumption influence on reduction of some parameters during plasma-aided pulverised-coal combustion: (a) nitrogen oxides concentration; (b) unburned carbon

\section{Conclusions}

PFS were developed, investigated and industrially tested and were found to improve coal combustion efficiency, while decreasing harmful emissions from pulverised-coal-fired thermal power plants.

PFS eliminate the need for expensive gas or oil fuels for startup, stabilisation of pulverised-coal flame and stabilisation of liquid slag output in furnaces with liquid slag removal.

PFS improve coal ignition and burnout without the need for increasing the mill temperature, augmenting the excess air factor or finer grinding.

\section{Acknowledgements}

The development of PFS was carried out under state contract with IT SB RAS (AAAA-A17-117030910025-7), the study of PFS in industrial power units was supported by the Ministry of Education and Science of the Republic of Kazakhstan (projects BR05236507, BR05236498, AP05130731 and AP05130031).

\section{REFERENCES}

Fine DH, Slater SM, Sarofim AF and Williams JC (1974) Nitrogen in coal as a source of nitrogen oxide emission from furnace. Fuel 53(2): 120-125, https://doi.org/10.1016/0016-2361(74)90067-2.

Gorokhovski MA, Jankoski Z, Lockwood FC et al. (2007) Enhancement of pulverized coal combustion by plasma technology. Combustion Science and Technology 179(10): 2065-2090, https://doi.org/ $10.1080 / 00102200701386115$.

Karpenko EI, Messerle VE and Ustimenko AB (2007) Plasma-aided solid fuel combustion. Proceedings of the Combustion Institute 31(Part II): 3353-3360, https://doi.org/10.1016/ j.proci.2006.07.038.
Karpenko El, Karpenko YE, Messerle VE and Ustimenko AB (2009) Using plasma-fuel systems at eurasian coal-fired thermal power stations. Thermal Engineering 56(6): 456-461, https://doi.org/ 10.1134/S0040601509060020.

Matveeva II, Novitski NV and Vdovchenko VS (1979) Power Generating Fuel of the USSR (Fossil Coal, Shale Oil, Peat, Fuel Oil and Gas Fuel). Handbook of Energy, Moscow, USSR.

Messerle VE and Ustimenko AB (2014) Plasma-aided coal ignition and combustion: modeling and full-scale trials. IEEE Transactions on Plasma Science 42(12): 3716-3721, https://doi.org/10.1109/ TPS.2014.2345871.

Messerle VE, Karpenko El, Ustimenko AB and Lavrichshev OA (2013) Plasma preparation of coal to combustion in power boilers. Fuel Processing Technology 107: 93-98, https://doi.org/10.1016/ j.fuproc.2012.07.001.

Messerle VE, Karpenko El and Ustimenko AB (2014) Plasma assisted power coal combustion in the furnace of utility boiler: numerical modelling and full-scale test. Fuel 126: 294-300, https://doi.org/ 10.1016/j.fuel.2014.02.047.

\section{How can you contribute?}

To discuss this paper, please email up to 500 words to the editor at journals@ice.org.uk. Your contribution will be forwarded to the author(s) for a reply and, if considered appropriate by the editorial board, it will be published as discussion in a future issue of the journal.

Proceedings journals rely entirely on contributions from the civil engineering profession (and allied disciplines).

Information about how to submit your paper online is available at www.icevirtuallibrary.com/page/authors, where you will also find detailed author guidelines. 